\title{
Self-Editing Activities Improve Recount Text Writing Skills
}

\author{
I Komang Janu Prianda Putra ${ }^{1 *}$, Ni Nyoman Padmadewi², Kadek Sintya Dewi ${ }^{3}$ iD \\ 1,2,3 Universitas Pendidikan Ganesha, Singaraja, Indonesia \\ *Corresponding author: januprianda@gmail.com
}

\begin{abstract}
Abstrak
Saat ini, siswa dituntut untuk menjadi pembelajar mandiri, dan itu menjadi lebih menantang di masa pandemi ini. Penelitian ini bertujuan untuk menganalisis penerapan aktivitas self-editing untuk meningkatkan keterampilan menulis recount teks pada siswa SMA. Penelitian ini merupakan penelitian eksperimen dengan desain penelitian yang digunakan ialah post-test only control group design. Data dikumpulkan dari siswa kelas X. Ada dua kelas yang dipilih untuk dijadikan sampel penelitian ini. Untuk memperoleh data, peneliti menggunakan tes menulis. Setelah diberikan treatment, siswa diberikan posttest tentang menulis teks recount. Tulisan siswa dinilai menggunakan rubrik penilaian menulis. Hasilnya dibandingkan dan diperiksa untuk mengetahui pengaruh aktivitas self-editing terhadap tulisan siswa. Selanjutnya, effect size diukur untuk mengetahui seberapa besar pengaruh aktivitas self-editing terhadap keterampilan menulis siswa khususnya pada teks recount. Hasil penelitian menunjukkan bahwa nilai rata-rata kelompok eksperimen adalah 83,05, dan kelompok kontrol adalah 80,26. Sedangkan simpangan baku pada kelompok eksperimen adalah 5,417, dan kelompok kontrol adalah 5,486. Berdasarkan hasil penelitian, dapat disimpulkan bahwa terdapat pengaruh yang signifikan dari aktivitas self-editing terhadap keterampilan menulis siswa, khususnya dalam menulis teks recount. Aktivitas ini bisa menjadi strategi pembelajaran yang berguna untuk diterapkan dalam proses belajar mengajar saat ini.
\end{abstract}

Kata kunci: Self-Editing, Teks Recount, Bahasa Inggris

\section{Abstract}

Currently, students must be independent learners, which becomes even more challenging during this pandemic. This study aims to analyze the application of self-editing activities to improve recount text writing skills in high school students. This research is experimental research with the research design used is post-test only control group design. Data were collected from class $X$ students. There were two classes selected to be the sample of this study. To obtain data, the researcher used a writing test. After being given treatment, students were given a post-test about writing recount text. Students' writing is assessed using a writing assessment rubric. The results were compared and examined to determine the effect of self-editing activities on students' writing. Furthermore, the effect size is measured to determine how much influence self-editing activities have on students' writing skills, especially in recount texts. The results showed that the average value of the experimental group was 83.05, and the control group was 80.26. While the standard deviation in the experimental group was 5.417, and the control group was 5.486. Based on the study results, it can be concluded that there is a significant effect of self-editing activities on students' writing skills, especially in writing recount texts. This activity can be a helpful learning strategy to be applied in the current teaching and learning process.

\section{INTRODUCTION}

The writing process is essential because these skills, apart from reading, listening, and speaking, are the most challenging (Rezaeian, 2013; Wei, 2020; Zhang, 2016). Students tend to confuse describing their ideas in written form. They have to think about the grammar, structure, organization of their writing. Editing and revising stages are considered to play an essential role in improving students' writing skills. The editing and revising stages have an essential function in writing to improve students' writing skills. At this stage, students can modify their mistakes to make their work readable. To achieve writing accuracy, students must dedicate their time to correcting errors found in writing. The errors faced by students are common difficulties that occur in the writing process. Some mistakes that are often made by students, especially in Indonesia, are problems with the use of grammar, plural forms, clauses, verb forms, and passive voice. In writing, students may face some difficulties that

\begin{tabular}{|c|c|c|}
\hline History: & & Publisher: Undiksha Press \\
\hline Received & : March 10, 2021 & Licensed: This work is licensed under \\
\hline Revised & : March 15, 2021 & a Creative Commons Attribution 3.0 License \\
\hline Accepted & : April 29, 2021 & (c) (†) () \\
\hline Published & : May 25, 2021 & (c) SY SA $_{\mathrm{SA}}$ \\
\hline
\end{tabular}


will affect the quality of their work (Krismasari Dewi et al., 2019; Pranata, 2013; Ratnayanti et al., 2016).

Based on the 2013 Curriculum, students learn several texts, including narrative texts, recount texts, descriptive texts, report texts, and others. Each type has its difficulties. Recount text is one of the challenging texts for students. Recount text is a type of text in English that retells events or experiences in the past (Jumasa \& Surjono, 2016; Sutarmi et al., 2013). The purpose of recount text is to provide information or entertain the reader so that there is no conflict. Types of recount text include a) personal recount, which tells about the author's personal experience. b) factual recount, namely reports of events, such as scientific experiment reports and police reports. c) imaginative, namely making imaginative stories and then writing down events or events that have occurred (Sianipar et al., 2020; Sitorus \& Sipayung, 2018). There are still some obstacles in writing recount texts experienced by students, including the students still lack organizing content and mechanical elements that make their work difficult to understand. In addition, they found some problems with the grammar and generic structure of the recount text. It can be concluded that writing recount text is still complicated for students to express their ideas and organize the structure of recount text.

Based on the results of interviews and observations, it was found that writing recount texts were challenging for tenth graders. Students were still difficult to express in recount texts. Some mistakes made by students in organizing their ideas are still found, and they find it challenging to use grammar and organize what they want to say to make a coherent structure of the recount text. They usually do not check what they write like they do not check the grammar and organization of their writing, which affects the quality of their work. There are three sources of feedback; teachers, peers, and students themselves. Students by themselves can provide corrections for their work.

These problems, if left unchecked, will harm the students' writing learning process. So a solution to this problem is needed. One solution that can be given is to apply learning with self-editing activities. Self-editing activities make students more active in the learning process. Students are required to be able to edit and correct their own mistakes in the learning process. In addition, this self-editing activity can also help teachers reduce the burden of teaching so much because students are the focus of learning and are more active during the learning process. Giving students the confidence to edit and correct their own mistakes can motivate them to improve and improve. There have not been many in-depth studies on selfediting in writing recount text.

Several studies that are in line with this research, such as research conducted by (Bai, 2018) found that it is important to understand students' use of self-editing writing strategies. Then research conducted by (Obisuru \& Purbani, 2016) found that learning to write through self-editing and self-correcting was proven to improve students' English writing skills. The difference between this research and previous research is that this research was conducted online. This study aimed to analyze the application of self-editing activities to improve recount text writing skills in high school students.

\section{MATERIALS AND METHODS}

This research is experimental research with the research design used is post-test only control group design (Sugiyono, 2016). This research was conducted at SMA N 2 Amlapura. This school is located in Karangasem, precisely on Jalan Untung Surapati, Amlapura. Data was collected from class X students of SMA N 2 Amlapura in 2020/2021. Two classes were chosen to be the samples of this study, namely X MIPA 3 as the control group and X MIPA 5 as the experimental group. To obtain data, the researcher used a writing test. After being 
given treatment, students were given a post-test about writing recount text. Student writing is assessed using a writing assessment rubric. The results were compared and examined to determine the effect of self-editing activities on students' writing. Furthermore, the effect size is measured to determine how much influence self-editing activities have on students' writing skills, especially in recount texts.

\section{RESULTS AND DISCUSSION}

Data analysis used IBM SPSS 25.0 for Windows to answer research questions. The research question is "Is there a significant effect of self-editing activity on students' writing skills in recount texts for tenth graders of SMA Negeri 2 Amlapura?". The sample of this study had the same number of students, where the experimental group consisted of 38 students and the control group. The groups were given the identical post-test in a writing test after the part as a treatment six times. The researcher manually checked the students' work using the written assessment rubric. The results of the descriptive analysis can be seen in Table 1.

Table 1. Post-test Descriptive Analysis

\begin{tabular}{ccc}
\hline Post-Test Score & Analysis & Statistics \\
\hline \multirow{3}{*}{ Experimental Group } & Means & 83.05 \\
& median & 83.05 \\
& Deviasi Std & 5.417 \\
& Distance & 24 \\
Control Group & Means & 80.26 \\
& median & 80.00 \\
& Deviasi Std & 5.486 \\
\hline
\end{tabular}

Descriptive statistics from the IBM SPSS program show that the mean score of the experimental group treated with self-editing activity was 83.05. While the average value of the control group that was given conventional learning treatment was 80.26. This means that the experimental group has a higher average value than the control group. After the descriptive analysis is done, then the inferential analysis is carried out. After the data were analyzed with normality and homogeneity tests and the results were normally distributed, and both groups were homogeneous, hypothesis testing was carried out. This analysis aims to find out the significant difference from the post-test results after the application of treatment in this study, which is a self-editing activity. The results of hypothesis testing can be seen in Table 2.

Table 2. Hypothesis Testing

\begin{tabular}{cccc}
\hline Post-Test Score & Signature & $\begin{array}{c}\text { Difference } \\
\text { Means }\end{array}$ & $\begin{array}{c}\text { Std. Error } \\
\text { Difference }\end{array}$ \\
\hline The same variance is assumed & 0.029 & 2.789 & 1.251 \\
Equal variance is not assumed & 0.029 & 2.789 & 1.251 \\
\hline
\end{tabular}

The results of hypothesis testing indicate that the null hypothesis (Ho), which states that there is no significant effect of self-editing activities on students' writing skills in recount texts, is rejected. This can be seen from the findings, which show a significance value (Sig2tailed) of 0.029. Thus, based on hypothesis testing, the alternative hypothesis is accepted. It 
can be concluded that there is a significant effect of self-editing activities on students' writing skills in recount texts at SMA N 2 Amlapura. The average value of the experimental group was 83.05, and the control group was 80.26. While the standard deviation in the experimental group was 5.417, and the control group was 5.486. Then, the value is calculated using the calculation of the Becker effect size. The results from the table above show that Cohen's $d$ is 0.51 . This indicates that the effect size is moderate.

This study was conducted to determine whether there is a significant effect of selfediting activities on students in the recount text writing class. In this study, researchers used two classes as experimental samples. There are two groups, namely the experimental group and the control group. Two classes of five classes were selected to be sampled using random cluster sampling. X MIPA 3 and X MIPA 5 were selected as samples of this study, and each group consisted of 38 students. The two groups were subjected to two different treatments. Experiments were treated by applying self-editing in their writing class. At the same time, the control group was given conventional teaching. Both groups were analyzed in the same topic or subject, namely, recount text. After the treatment was carried out, a post-test was carried out. The post-test aims to determine the results of the application of this research treatment. Then, the results of the post-test scores of the two groups were analyzed.

Students who study with self-editing activities in their writing class score better on average than those who study with conventional teaching. Descriptive statistics from the IBM SPSS program show that the mean score of the experimental group treated with self-editing activity was 83.05. While the average value of the control group that was given conventional learning treatment was 80.26. This means that the experimental group has a higher average value than the control group. It can be concluded that students perform better when implementing self-editing activities in their writing class, especially recount text. Based on these findings, self-editing is helpful for learning to write at SMA N 2 Amlapura. According to students' writing results, students find it easier to revise or edit with the correction symbols provided by the self-editing activity. Students usually do not check or change their previous writing, and this correction symbol makes them look at their writing longer. The findings of this study indicate that students are used to checking their writing using correction symbols.

Self-editing activities help them to improve the quality of their writing. Students' selfediting activities enable them to identify and correct their writing so that after training them in self-editing, they know how to edit their writing independently (Attiya et al., 2021; Mawlawi Diab, 2010; Sulistyawati \& Mustofa, 2020). The students' ability has significantly improved after participating in learning writing editing skills in their learning. Improvements in grammatical structure, word form, collocation, spelling, and punctuation significantly increased the students' work. This study also found that students improved their writing in terms of organization, grammatical structure, and mechanics. Self-editing activities can allow students to improve their writing individually, and it can help them improve their writing skills development during this pandemic. Students can provide corrections for their writing errors. To help students edit or correct their mistakes in writing, students can use some correction symbols that can help students practice editing themselves. This correction symbol can guide students in finding out what mistakes they made. Several steps for teaching students to do self-editing or self-correcting can be applied in the writing process: finding errors, correcting symbols for understanding, removing symbols gradually, and making corrections (Ebadi \& Rahimi, 2017; Makhrus \& Cahyani, 2016). These steps can be a guide for teachers as well. The students get plenty of time to practice their self-editing skills by doing the steps. 


\section{CONCLUSION}

There is a significant effect of self-editing activities on students' writing skills, especially recount texts. This activity can be a helpful learning strategy to be applied in the current teaching and learning process.

\section{REFERENCES}

Attiya, H., Burckhardt, S., Gotsman, A., Morrison, A., Yang, H., \& Zawirski, M. (2021). Specification and space complexity of collaborative text editing. Theoretical Computer Science, 855, 141-160. https://doi.org/10.1016/j.tcs.2020.11.046.

Bai, B. (2018). Understanding primary school students' use of self-regulated writing strategies through think-aloud protocols. System, 78, 15-26. https://doi.org/10.1016/j.system.2018.07.003.

Ebadi, S., \& Rahimi, M. (2017). Exploring the impact of online peer-editing using Google Docs on EFL learners' academic writing skills: a mixed methods study. Computer Assisted Language Learning, 30(8), 787-815. https://doi.org/10.1080/09588221.2017.1363056.

Jumasa, M. A., \& Surjono, H. D. (2016). Pengembangan Multimedia Pembelajaran Bahasa Inggris utuk Pembelajaran Teks Recount di MTSN II Yogyakarta. Jurnal Inovasi Teknologi Pendidikan, 3(1), 25. https://doi.org/10.21831/tp.v3i1.8287.

Krismasari Dewi, N. N., Kristiantari, M. . R., \& Ganing, N. N. (2019). Pengaruh Model Pembelajaran Picture and Picture Berbantuan Media Visual Terhadap Keterampilan Menulis Bahasa Indonesia. Journal of Education Technology, 3(4), 278. https://doi.org/10.23887/jet.v3i4.22364.

Makhrus, M., \& Cahyani, P. D. (2016). Pelatihan Creative Writhink Pada Ikatan Pelajar Muhammadiyah Kabupaten Banyumas. Islamidina Jurnal Pendidikan Islam, 17(2). http://dx.doi.org/10.30595/islamadina.v0i0.1325.

Mawlawi Diab, N. (2010). Effects of peer- versus self-editing on students' revision of language errors in revised drafts. System, 38(1), 85-95. https://doi.org/10.1016/j.system.2009.12.008.

Obisuru, M., \& Purbani, W. (2016). Kemampuan menulis bahasa Inggris siswa melalui selfediting and self-correcting berdasarkan analisis kesalahan gramatikal dan kosakata. LingTera, 3(1), 51. https://doi.org/10.21831/lt.v3i1.8473.

Pranata, I. K. A. K. (2013). Penggunaan Teknik 3-P untuk Meningkatkan Kemampuan Menulis Berita Berbasis 5W+1H Siswa Kelas VIII A SMP Negeri 7 Singaraja. Jurnal Pendidikan Bahasa dan Sastra Undiksha, http://dx.doi.org/10.23887/jjpbs.v1i1.282.

Ratnayanti, N. M. D., Jampel, I. N., \& Sudana, D. N. (2016). Penerapan Metode Journalist Question (5W1H) Berbantuan Media Foto Pribadi untuk Meningkatkan Keterampilan Menulis Narasi Kelas III. Mimbar PGSD Undiksha, 4(1). http://dx.doi.org/10.23887/jjpgsd.v4i1.7004.

Rezaeian, M. (2013). The application of publication guidelines should extend to cover their designing stage and protocol writing. Annals of Epidemiology, 23(12), 815. https://doi.org/10.1016/j.annepidem.2013.06.092.

Sianipar, R. B., Sianturi, D. S., Situmorang, S. A., Gulo, P., \& Saragih, E. (2020). an Analysis of Recount Text in English Textbooks Used By Tenth Grade Students. Journal of Languages and Language Teaching, 8(2), 120. https://doi.org/10.33394/jollt.v8i2.2280.

Sitorus, G. S., \& Sipayung, K. (2018). An Error Analysis of Using Phrases in Writing Recount Text at Tenth Grade in SMA Parulian 2 Medan. Celt: A Journal of Culture, 
$\begin{array}{lllll}\text { English Language Teaching \& } & \text { Literature, }\end{array}$ https://doi.org/10.24167/celt.v18i1.562.

Sugiyono. (2016). Metode Penelitian Kualitatif, Kuantitatif, dan R\&D. Alfabeta.

Sulistyawati, E., \& Mustofa, A. (2020). Peer Editing in Efl Writing Classroom. Jurnal Education and ..., 8(3), 242-249. http://journal.ipts.ac.id/index.php/ED/article/view/1946.

Sutarmi, N. W., Suharsono, N., \& Warpala, S. (2013). Pengaruh Pembelajaran Scaffolding Terhadap Keterampilan Menulis Teks Recount Berbahasa Inggris Dan Kreativitas Siswa Kelas VIII SMP Negeri 3 Manggis. Jurnal Teknologi Pembelajaran Indonesia, 3(1). https://doi.org/10.23887/jtpi.v3i1.897.

Wei, X. (2020). Assessing the metacognitive awareness relevant to L1-to-L2 rhetorical transfer in L2 writing: The cases of Chinese EFL writers across proficiency levels. Assessing Writing, 44. https://doi.org/10.1016/j.asw.2020.100452.

Zhang, L. J. (2016). Reflections on the pedagogical imports of western practices for professionalizing ESL/EFL writing and writing-teacher education. Australian Review of Applied Linguistics, 39(3), 203-232. https://doi.org/10.1075/aral.39.3.01 zha. 